\title{
EKSPERIMENTASI PEMBELAJARAN MATEMATIKA DENGAN MODEL PROBLEM BASED INSTRUCTION DAN GROUP INVESTIGATION PADA MATERI PECAHAN KELAS IV SD SE-KECAMATAN PANCUR DITINJAU DARI MINAT BELAJAR SISWA
}

\author{
Oleh : Sumaji PGSD FKIP Universitas Muria Kudus \\ Email : smaji23@yahoo.com
}

\begin{abstract}
The Purpose of this reseach was to find out: (1) which model gives better learning achievement, group investigation, problem based instruction or direct model, (2) which students has better achievement, student with high interest in learning, middle, or low interest in learning, and (3) in each interest in learning, which model gives better learning achievement, group investigation learning model, problem based instruction, or direct one.

Research method used was quasi experimental research with factorial 3x3. Research was held in 2012/2013 and the population was class IV students of SD in Pancur. Sample was taken by technique of Stratified Cluster Random Sampling. Data was collected by method of test, documentation and questionnaire. Before using those instruments, I tried out a test in Class IV SD Criwik. Test Instrument Analysis used content validity by experts judgment and reliability of test uses $\mathrm{KR}-20$, and the test analysis consist of distinguishing and difficulty level. Questionnaire instrument test uses content validity by experts judgment, questionnaire reliability uses Cronbach Alpha, questionnaire analysis uses internal consistency test. Before data was analyzed, I do prerequisite test, that was a normality test with Liliefors method, and homogenitas test with Bartlett test. Technique of data analysis in this research uses two ways-Avana Analysis with the different cell, and it is continued by post hoc comparisons test with Scheffe' method.

Based on the data analysis, the results of this research are as follows. (1) Learning model of Problem Based Instruction gives better learning achievement of Mathematics than Group Investigation and the Direct one. Learning model of Group Investigation gives better learning achievement of Mathematics than direct leaning model, (2) Students with high interest in learning has better learning achievement of mathematics than students with middle interest in learning and the low one and students with middle interest in learning has better learning achievement of mathematics than students with the low one, and (3) The students with high, middle, and low interest in learning, learning model of Problem Based Instruction gives better learning achievement of mathematics than learning model of Group Investigation and the direct one and Learning model of Group Investigation gives better learning achievement than the direct one.

Keywords: Mathematics Learning, Problem Based Instruction, Group Investigation, Intererst in Learning .
\end{abstract}

\section{PENDAHULUAN}

Hasil belajar matematika siswa SD masih rendah. Hal ini dikarenakan pembelajaran masih berpusat pada siswa. Siswa belum diberi kesempatan untuk memecahkan masalah matematika. Kondisi ini menunjukkan bahwa reformasi dalam sistem pendidikan nasional kita sudah menjadi suatu keharusan yang tidak bisa ditunda lagi, terutama pada jenjang pendidikan dasar yang menjadi landasan bagi pengembangan pendidikan pada jenjang selanjutnya. Keberhasilan siswa dalam belajar juga dipengaruhi minat siswa dalam belajar. Minat setiap siswa untuk 
menerima materi yang diberikan oleh guru berbeda-beda, selain itu setiap siswa juga memiliki karakteristik yang berbeda. Oleh karena itu guru harus menerapkan model pembelajaran kooperatif yang menarik, efektif dan interaktif. Banyak model pembelajaran kooperatif diantaranya model pembelajaran Think Phare Share, CTL, Jigzaw, STAD, Group Investigation, dan Problem Based Learning. Menurut Khanafiyah dan Yulianti (2013) Problem Based Instruction merupakan rangkaian aktivitas pembelajaran yang menekankan pada proses penyelesaian masalah. Sedangkan menurut Arends, (2008) model pembelajaran Problem Based Instruction adalah merupakan suatu model pembelajaran dimana siswa mengerjakan permasalahan yang otentik dengan maksud untuk menyusun pengetahuan mereka sendiri, mengembangkan inkuiri dan keterampilan berpikir tingkat tinggi, mengembangkan kemandirian dan percaya diri.

Sedangkan model Group Investigation guru perlu menilai

\section{METODE PENELITIAN}

Penelitian ini adalah merupakan penelitian eksperimental semu dengan desain faktorial $3 \times 3$. Populasi penelitian adalah siswa kelas IV SDN seKecamatan Pancur tahun pelajaran kemampuan siswa untuk merencanakan pembelajaran, memilih topik yang sesuai untuk Group Investigation, berpikir berdasarkan pertanyaan-pertanyaan yang muncul dari permasalahan, dan menggunakan berbagai sumber untuk bahan pembelajaran. Beberapa penelitian yang telah dilakukan terkait dengan pengaruh model pembelajaran Group Investigation terhadap prestasi belajar matematika diantaranya adalah: (1) Eko Susanto (2011), melakukan penelitian di kelas IV SD Negeri di kabupaten Madiun. Hasil penelitian yang telah dilakukan menunjukkan bahwa model pembelajaran Group Investigation memberikan prestasi belajar lebih baik daripada model pembelajaran Langsung, dan (2) Adi Paryanto (2011), melakukan penelitian di kelas V SD Negeri di kabupaten Sragen. Hasil penelitian yang telah dilakukan menunjukkan bahwa model pembelajaran Group Investigation memberikan prestasi belajar lebih baik daripada model pembelajaran Langsung.

2012/2013. Penelitian dilakukan di SD 1 Pancur, SD Wuwur, dan SD 2 Pancur, SD Sumberagung, SD Kalitengah, SD dan SD Tuyuhan SD Kedung, SD Johogunung, dan SD Ngroto, dengan sampel 196 siswa. 
Dari masing-masing sekolah diambil satu kelas secara acak sebagai kelas eksperimen I, II dan kelas kontrol. Uji homogenitas menggunakan uji Bartlett, uji normalitas menggunakan Lilliefors dan uji keseimbangan menggunakan uji anava satu jalan. Hasil analisis, sampel berasal dari populasi yang berdistribusi normal, mempunyai variansi yang homogen, dan memiliki kemampuan awal yang sama. Metode yang digunakan dalam mengumpulkan data adalah : (1) metode angket, (2) metode dokumentasi, dan (3) metode tes. Instrumen dalam penelitian ini adalah: (1) tes hasil belajar dan (2) kuisioner angket minat siswa. Analisis data dilakukan dengan Anava dua jalan sel tak sama.

Dalam penelitian ini terdapat variabel terikat dan variabel bebas. Uji coba instrumen dilakukan di SD Criwik dengan responden 20 siswa. Berdasarkan hasil uji validitas isi, daya beda ( $\left.r_{x y} \geq 0,3\right)$, tingkat kesulitan $(0,3 \leq T K \leq 0,70)$ dan reliabilitas $\geq 0,7$, dari 40 butir soal yang diujicobakan dieroleh 25 butir soal yang baik. Sedangkan berdasarkan hasil uji validitas isi, reliabilitas Alpha Cronbach $\left(r_{x y} \geq 0,7\right)$ dan konsistensi internal $\left(r_{x y} \geq 0,3\right)$, dari 40 butir pernyataan yang diujicobakan diperoleh 30 butir pernyataan yang dapat digunakan untuk mengambil data minat belajar siswa. Uji prasyarat analisis yaitu uji normalitas dengan Lilliefors dan uji homogenitas dengan uji Bartlett. Dari hasil perhitungan diperoleh prasyarat normalitas dan homogenitas data, sehingga dapat dilakukan analisis data menggunakan anava dua jalan dengan sel tak sama.

\section{HASIL PENELITIAN DAN PEMBAHASAN}

Tabel 1 Rangkuman Analisis Variansi Dua Jalan Dengan Sel Tak Sama

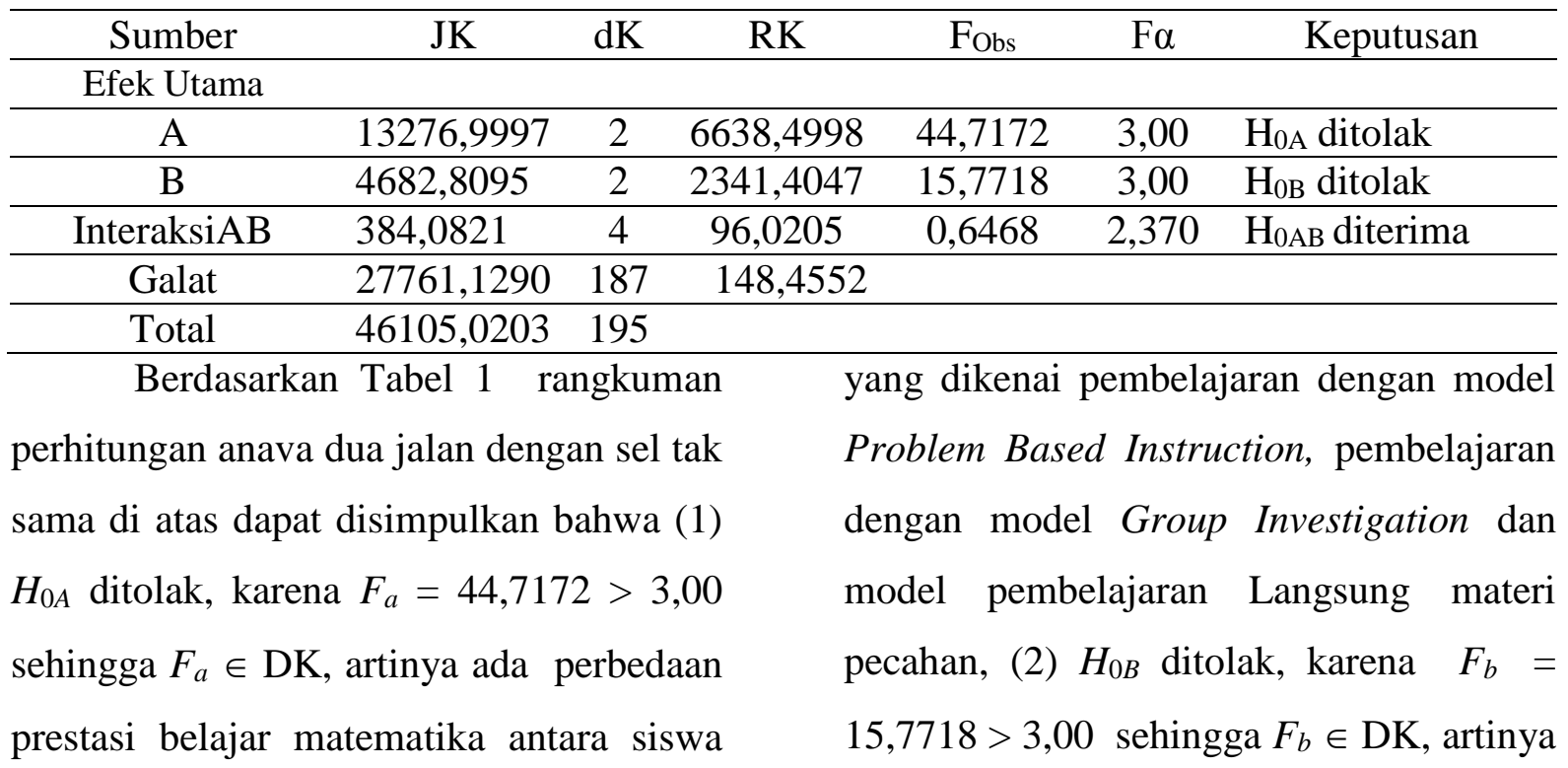


ada perbedaan prestasi belajar matematika antara siswa yang mempunyai aktivitas belajar tinggi, siswa yang mempunyai minat belajar sedang dan rendah pada materi pecahan, dan (3) $H_{0 A B}$ diterima, karena $F_{a b}=0,6468<2,370$ sehingga $F_{a b}$ $\notin \mathrm{DK}$, artinya tidak ada interaksi antara model pembelajaran dengan aktivitas belajar siswa pada materi pecahan. $H_{0 A}$ dan $H_{0 B}$ ditolak, maka perlu dilakukan uji lanjut pasca anava. Sedangkan $H_{0 A B}$ diterima, maka tidak perlu dilakukan komparasi pasca anava antar sel.

Tabel 2 Rataan Antar Sel

\begin{tabular}{lcccc}
\hline \multirow{2}{*}{ Model } & \multicolumn{3}{c}{ Minat belajar } & \multirow{2}{*}{ Rataan Marginal } \\
\cline { 2 - 4 } & Tinggi $\left(\mathrm{B}_{1}\right)$ & Sedang $\left(\mathrm{B}_{2}\right)$ & Rendah $\left(\mathrm{B}_{3}\right)$ & \\
\hline $\begin{array}{l}\text { Pembelajaran Problem } \\
\text { Based Instruction }\left(\mathrm{A}_{1}\right)\end{array}$ & 83,1795 & 78,7200 & 69,5000 & 80,1111 \\
\hline $\begin{array}{l}\text { Group Investigation } \\
\left(A_{2}\right)\end{array}$ & 80,6667 & 76,3478 & 66,0000 & 73,6146 \\
\hline Langsung $\left(\mathrm{A}_{3}\right)$ & 63,4286 & 54,3529 & 52,4286 & 55,5932 \\
\hline Rataan Marginal & 78,6479 & 71,5077 & 60,1333 & \\
\hline
\end{tabular}

Tabel 3 Rangkuman Uji Komparasi Ganda Antar Baris

\begin{tabular}{llllll}
\hline Komparasi & $\mathrm{H}_{0}$ & $\mathrm{H}_{1}$ & $\mathrm{~F}_{\text {Obs }}$ & $2 \mathrm{~F}_{0,05 ; 2 ; 269}$ & Keputusan Uji \\
\hline$\mu_{1}$ vs $\mu_{2 .}$ & $\mu_{1 .}=\mu_{2 .}$ & $\mu_{1 .} \neq \mu_{2 .}$ & 6,1405 & $2(3,00)=6$ & $\mathrm{H}_{0}$ ditolak \\
\hline$\mu_{1}$ vs $\mu_{3}$. & $\mu_{1 .}=\mu_{3 .}$ & $\mu_{1 .} \neq \mu_{3}$. & 118,5409 & $2(3,00)=6$ & $\mathrm{H}_{0}$ ditolak \\
\hline$\mu_{2}$ vs $\mu_{3 .}$ & $\mu_{2 .}=\mu_{3 .}$ & $\mu_{2 .} \neq \mu_{3 .}$ & 68,4758 & $2(3,00)=6$ & $\mathrm{H}_{0}$ ditolak \\
\hline
\end{tabular}

Berdasarkan Tabel 3 di atas dapat disimpulkan bahwa (1) pada uji hipotesis $\mu_{1} \quad$ vs $\mu_{2} \quad \mathrm{H}_{0}$ ditolak, maka dapat disimpulkan ada perbedaan yang signifikan antara prestasi belajar matematika siswa yang dikenai model pembelajaran Problem Based Instruction dan model pembelajaran Group Investigation. Berdasarkan Tabel 2 di atas, rataan marginal untuk model Problem Based Instruction adalah 80,1111 dan model Group Investigation adalah 73,6146, sehingga dapat disimpulkan bahwa model pembelajaran Problem
Based Instruction memberikan prestasi belajar matematika lebih baik daripada model pembelajaran Group Investigation pada materi pecahan, (2) pada uji hipotesis $\mu_{1} \quad$ vs $\mu_{3} \quad \mathrm{H}_{0}$ ditolak, maka dapat disimpulkan ada perbedaan yang signifikan antara prestasi belajar matematika pada siswa yang dikenai model pembelajaran Problem Based Instruction dan model pembelajaran Langsung. Berdasarkan Tabel 2 di atas, rataan marginal untuk model Problem Based Instruction adalah 80,1111 dan model pembelajaran Langsung adalah 
55,5932, sehingga dapat disimpulkan bahwa model pembelajaran Problem Based Instruction memberikan prestasi belajar lebih baik daripada model pembelajaran Langsung pada materi pecahan, dan (3) pada uji hipotesis $\mu_{2}$ vs $\mu_{3}$ $\mathrm{H}_{0}$ ditolak, maka dapat disimpulkan ada perbedaan yang signifikan antara prestasi belajar matematika siswa yang dikenai model pembelajaran Group Investigation dan model pembelajaran Langsung. Berdasarkan Tabel 2 di atas, rataan marginal untuk model Group Investigation adalah 73,6146 dan model langsung adalah 55,5932, sehingga dapat disimpulkan bahwa model pembelajaran Group Investigation memberikan prestasi belajar matematika lebih baik daripada model pembelajaran Langsung pada materi pecahan.

Tabel 4 Rangkuman Uji Komparasi Ganda Antar Kolom

\begin{tabular}{llllll}
\hline Komparasi & $\mathrm{H}_{0}$ & $\mathrm{H}_{1}$ & Fobs & $2 \mathrm{~F}_{0,05 ; 2 ; 269}$ & Keputusan Uji \\
\hline$\mu_{1}$ vs $\mu_{2 .}$ & $\mu_{1}=\mu_{2}$. & $\mu_{1} \neq \mu_{2 .}$ & 16,4917 & $2(3,00)=6$ & $\mathrm{H}_{0}$ ditolak \\
\hline$\mu_{1}$ vs $\mu_{3 .}$ & $\mu_{1}=\mu_{3}$. & $\mu_{1} \neq \mu_{3 .}$ & 75,0878 & $2(3,00)=6$ & $\mathrm{H}_{0}$ ditolak \\
\hline$\mu_{2}$ vs $\mu_{3 .}$ & $\mu_{2}=\mu_{3 .}$ & $\mu_{2} \neq \mu_{3 .}$ & 21,1027 & $2(3,00)=6$ & $\mathrm{H}_{0}$ ditolak \\
\hline
\end{tabular}

Berdasarkan Tabel 4 di atas dapat disimpulkan bahwa (1) pada uji hipotesis $\mu_{1} \quad$ vs $\mu_{2} \mathrm{H}_{0}$ ditolak, maka dapat disimpulkan ada perbedaan yang signifikan antara prestasi belajar matematika siswa dengan minat belajar tinggi dan siswa dengan minat belajar sedang. Berdasarkan Tabel 2 di atas, rataan marginal untuk minat belajar tinggi adalah 78,6479 dan minat belajar sedang adalah 71,5077, sehingga dapat disimpulkan bahwa siswa dengan minat belajar tinggi mempunyai prestasi belajar lebih baik daripada minat belajar sedang pada materi pecahan, (2) pada uji hipotesis $\mu_{1} \quad$ vs $\mu_{3} \quad \mathrm{H}_{0}$ ditolak, maka dapat disimpulkan ada perbedaan yang signifikan antara prestasi belajar matematika siswa dengan minat belajar tinggi dan prestasi belajar matematika siswa dengan minat belajar rendah. Berdasarkan Tabel 2 di atas, rataan marginal untuk minat belajar tinggi adalah 78,6479 dan minat belajar rendah adalah 60,1333, sehingga dapat disimpulkan bahwa siswa dengan minat belajar tinggi mempunyai prestasi belajar matematika lebih baik daripada minat belajar rendah pada materi pecahan, (3) pada uji hipotesis $\mu_{2} \quad$ vs $\mu_{3} \mathrm{H}_{0}$ ditolak, maka dapat disimpulkan ada perbedaan yang signifikan antara prestasi belajar matematika siswa dengan minat belajar sedang dan siswa dengan minat belajar rendah. Berdasarkan Tabel 2 di atas, rataan marginal untuk minat belajar sedang 
adalah 71,5077 dan minat belajar rendah adalah 60,1333, sehingga dapat disimpulkan bahwa siswa dengan minat belajar sedang mempunyai prestasi belajar lebih baik daripada minat belajar rendah pada materi pecahan.

Berdasarkan hasil analisis variansi dua jalan disimpulkan bahwa tidak terdapat interaksi antara minat belajar dengan model pembelajaran. Ini menunjukkan bahwa perbedaan prestasi belajar materi pecahan dari minat belajar pada masing-masing model pembelajaran mengikuti karakteristik yang ada pada efek utamanya, sehingga dapat disimpulkan bahwa (1) pada siswa dengan minat belajar tinggi, sedang dan rendah model pembelajaran Problem Based Instruction memberikan prestasi belajar matematika lebih baik daripada model pembelajaran Group Investigation maupun Langsung dan model pembelajaran Group Investigation memberikan prestasi belajar matematika lebih baik daripada model pembelajaran Langsung, (2) pada kelompok siswa yang dikenai model pembelajaran Problem Based Instruction, group Investigaton dan pembelajaran Langsung, siswa dengan minat belajar tinggi mempunyai prestasi belayang lebih baik daripada siswa dengan minat belajar sedang dan rendah, sedangkan siswa dengan minat belajar sedang mempunyai prestasi belajar matematika yang lebih baik daripada siswa dengan minat belajar rendah.

Berdasarkan hasil analisis data tersebut di atas, dapat disimpulkan bahwa prestasi belajar matematika pada materi pecahan dengan model pembelajaran Problem Based Instruction memberikan prestasi belajar matematika lebih baik daripada model pembelajaran Group Investigation maupun Langsung, dan pembelajaran model Group Investigation memberikan prestasi belajar matematika yang lebih baik daripada dengan model pembelajaran Langsung. Hal ini sesuai dengan kajian teori bahwa pada model Problem Based Instruction proses pembelajaran yang berpusat pada siswa, dilakukan suasana saling kerjasama dan berinteraksi antar siswa dalam kelompok, siswa dilibatkan dalam proses pembelajaran sehingga dapat menyerap materi dengan baik. Pada model Group Investigation guru harus menilai kemampuan siswa untuk merencanakan pembelajaran, memilih topik, berpikir berdasarkan pertanyaan-pertanyaan yang muncul dari permasalahan yang ada. Sedangkan model pembelajaran Langsung memandang bahwa proses pembelajaran yang dilakukan sebagaimana umumnya guru mengajarkan materi kepada siswanya. Guru menstransfer ilmu pengetahuan 
kepada siswa, sedangkan siswa pasif menunggu informasi dari guru, (2) berdasarkan uji pasca anava dengan melihat rataan marginalnya pada Tabel 2 dapat disimpulkan bahwa siswa dengan minat belajar tinggi mempunyai prestasi belajar matematika yang lebih baik daripada siswa dengan minat belajar sedang maupun rendah, dan siswa dengan minat belajar sedang mempunyai prestasi belajar yang lebih baik daripada siswa dengan minat belajar rendah. Hal ini dikarenakan bahwa siswa yang berminat belajar tinggi akan mempunyai perasaan senang dalam proses pembelajaran, memperhatikan dalam pembelajaran, mempunyai konsentrasi tinggi dalam pembelajaran. Siswa yang minat belajarnya sedang perasaan dalam belajarnya sedang-sedang saja, cukup konsentrasi dalam pembelajaran, sedangkan siswa yang minat belajarnya rendah cepat bosan dalam pembelajaran, hal ini sejalan dengan pendapat Slameto (2003) minat adalah suatu rasa lebih suka dan rasa keterikatan pada suatu hal atau aktivitas tanpa ada yang menyuruh, dan (3) berdasarkan hasil analisis variansi dua jalan disimpulkan bahwa tidak terdapat interaksi antara minat belajar dengan model pembelajaran. Ini menunjukkan bahwa perbedaan prestasi belajar materi pecahan dari minat belajar pada masing- masing model pembelajaran mengikuti karakteristik yang ada pada efek faktor A (model pembelajaran), sehingga dapat disimpulkan bahwa pada siswa dengan minat belajar tinggi, sedang dan rendah model pembelajaran Problem Based Instruction memberikan prestasi belajar matematika lebih baik daripada model pembelajaran Group Investigation maupun Langsung dan model pembelajaran Group Investigation memberikan prestasi belajar matematika lebih baik daripada model pembelajaran Langsung.

\section{SIMPULAN DAN SARAN}

Berdasarkan kajian teori, analisis data dan perumusan masalah yang telah diuraikan, maka dapat di simpulkan bahwa (1) Pembelajaran dengan model pembelajaran Problem Based Instruction memberikan prestasi belajar matematika yang lebih baik daripada model pembelajaran Group Investigation maupun Langsung, dan model pembelajaran Group Investigation memberikan prestasi belajar matematika lebih baik daripada model pembelajaran Langsung, (2) siswa dengan minat belajar tinggi mempunyai prestasi belajar matematika yang lebih baik daripada siswa dengan minat belajar sedang maupun rendah, dan siswa dengan minat belajar sedang mempunyai prestasi belajar matematika yang lebih baik daripada siswa dengan minat belajar 
rendah, (3) pada siswa dengan minat belajar tinggi, sedang dan rendah model pembelajaran Problem Based Instruction memberikan prestasi belajar matematika lebih baik daripada model pembelajaran Group Investigation maupun Langsung dan model pembelajaran Group Investigation memberikan prestasi belajar matematika lebih baik daripada model pembelajaran Langsung.

Berdasarkan kesimpulan hasil penelitian disampaikan beberapa saran antara lain : (1) kepada guru: sebaiknya guru matematika mau mencoba model pembelajaran Problem Based Instruction dan Group Investigation dalam mengajar materi pecahan, selanjutnya mau melakukan refleksi untuk agar diperoleh hasil yang optimal, dan mencoba untuk materi yang lainnya, (2) kepada siswa: sebaiknya siswa dalam proses kegiatan pembelajaran matematika berlangsung, terlibat aktif dan memiliki perasaan senang sehingga proses pembelajaran berjalan secara optimal, dan (3) kepada peneliti selanjutnya: sebelum memilih model Problem Based Instruction dan Group Investigation sebaiknya kesesuaian materi dan kemampuan siswa perlu diperhatikan.

\section{DAFTAR PUSTAKA}

Adi Paryanto. 2011. "Pembelajaran Matematika melalui Pembelajaran matematika Realistik dan Group Investigation di tinjau dari Sikap Ilmiah Siswa. "Tesis tidak diterbitkan. Surakarta: PPs Universitas Sebelas Maret Surakarta.

Arends, RI.2008. Learning to Teach. Belajar untuk Mengajar. Buku Dua. Edisi Ketujuh. Terjemahan Helly Prajitno Soejidno, dan Sri Mulyani Soejipto. Yogyakarta : Pustaka Pelajar.

Eko Sutanto. 2011. "Pembelajaran matematika dengan cooperative Problem Solving dan Group Investigation ditinjau dari motivasi berprestasi dan sikap sosial siswa. " Tesis tidak diterbitkan. Surakarta: PPs Universitas Sebelas Maret Surakarta.

Khanafiyah, S \& Yulianti D. 2013. Model Problem Based Instruction pada Perkuliahan Fisika Lingkungan Untuk Mengembangkan Sikap Kepedulian Lingkungan. Jurnal Pendidikan Fisika Indonesia 9 (2013) : 35-42.

Slameto. 2003. Belajar dan Faktor-faktor yang Mempengaruhinya. Jakarta: PT Rineka Cipta. 